\title{
PENGARUH KOMPETENSI DAN INDEPENDENSI AUDITOR TERHADAP KUALITAS AUDIT PADA AUDIT MUTU INTERNAL ISO 9001:2008 DI UNIVERSITAS BUNDA MULIA, JAKARTA
}

\author{
Yustinus Yuniarto \\ Fakultas Ilmu Sosial dan Humaniora, Universitas Bunda Mulia \\ email: yyuniarto@bundamulia.ac.id
}

\begin{abstract}
This study discusses about "Effect of Competence and Auditor independency on the Quality Audit on Internal Quality Audit System ISO 9001: 2008 at the University of Bunda Mulia". The purpose of this study to determine how much influence the competence and independence of the quality audit on internal quality audit system is ISO 9001 so that it can be made in the audit strategy and the determination of the auditor. In this research produced the conclusion that the value of the regression coefficient competence (XI) of 0.022 and has significant value $<0.05$ proves that competence significant effect on audit quality. Then the value of the independence of the regression coefficient (X2) is 0,747dan have significant value $>0.05$ proving that independence had no significant effect on audit quality.
\end{abstract}

Calculated $F$ value of 4.767> F table at 4.11 and significant value of $0.032<$ alpha value of 0.05. This means there is a simultaneous effect between competence and independence to audit quality.

Keywords: internal quality audits, internal auditor, competence, independence, quality audits, ISO 9001: 2008

\begin{abstract}
Abstrak
Penelitian ini membahas mengenai "Pengaruh Kompetensi dan Indepedensi Auditor terhadap Kualitas Audit pada Audit Mutu Internal Sistem ISO 9001 : 2008 di Universitas Bunda Mulia". Tujuan penelitian ini untuk mengetahui seberapa besar pengaruh kompetensi dan independensi terhadap kualitas audit pada audit mutu internal sistem ISO 9001 sehingga dapat dibuat strategi dalam pelaksanaan audit maupun dalam penentuan auditor. Pada penelitian ini dihasilkan kesimpulan bahwa besarnya nilai koefisien regresi kompetensi $\left(\mathrm{X}_{1}\right)$ sebesar 0,022 dan mempunyai nilai signifikan $<0,05$ membuktikan bahwa kompetensi berpengaruh signifikan terhadap kualitas audit. Lalu besarnya nilai koefisien regresi independensi $\left(\mathrm{X}_{2}\right)$ sebesar 0,747 dan mempunyai nilai signifikan $>0,05$ membuktikan bahwa independensi tidak berpengaruh signifikan terhadap kualitas audit. Nilai $\mathrm{F}$ hitung sebesar 4,767 > F tabel sebesar 4.11 dan nilai signifikan $0,032<$ nilai alpha 0,05. Ini berarti ada pengaruh secara simultan antara kompetensi dan independensi terhadap kualitas audit.

Kata Kunci: audit mutu internal, auditor internal, kompetensi, independensi, kualitas audit, ISO $9001: 2008$.
\end{abstract}

\section{PENDAHULUAN}


Implementasi ISO 9001:2008 pada awalnya hanya dianggap sebagai tuntutan pasar (market driven). Namun dalam perkembangannya ternyata memberikan banyak sekali nilai tambah bagi perusahaan yang menerapkan. Standar Sistem Manajemen Mutu ISO 9001: 2008 mempunyai pengaruh baik untuk jangka pendek ataupun jangka panjang dan mempunyai penerapan taktis ataupun strategis, seperti peningkatan produktivitas, peningkatan efesiensi, penurunan biaya, dan peningkatan pelanggan.
Penggunaan ISO 9000 tidak hanya bagi perusahaan jasa akan tetapi juga sudah diterapkan pada bidang pendidikan. Seperti Universitas Bunda Mulia yang telah menerapkan sejak tahun 2008. Rentang waktu yang sudah beberapa tahun tersebut tentunya memerlukan auditor internal untuk menjalani fungsi audit internal.

Sebagai gambaran akan pelaksanaan audit internal di lingkungan Universitas Bunda Mulia maka laporan temuan audit internal selama 3 tahun yaitu tahun 2012 sampai dengan tahun 2014 sebagai berikut:

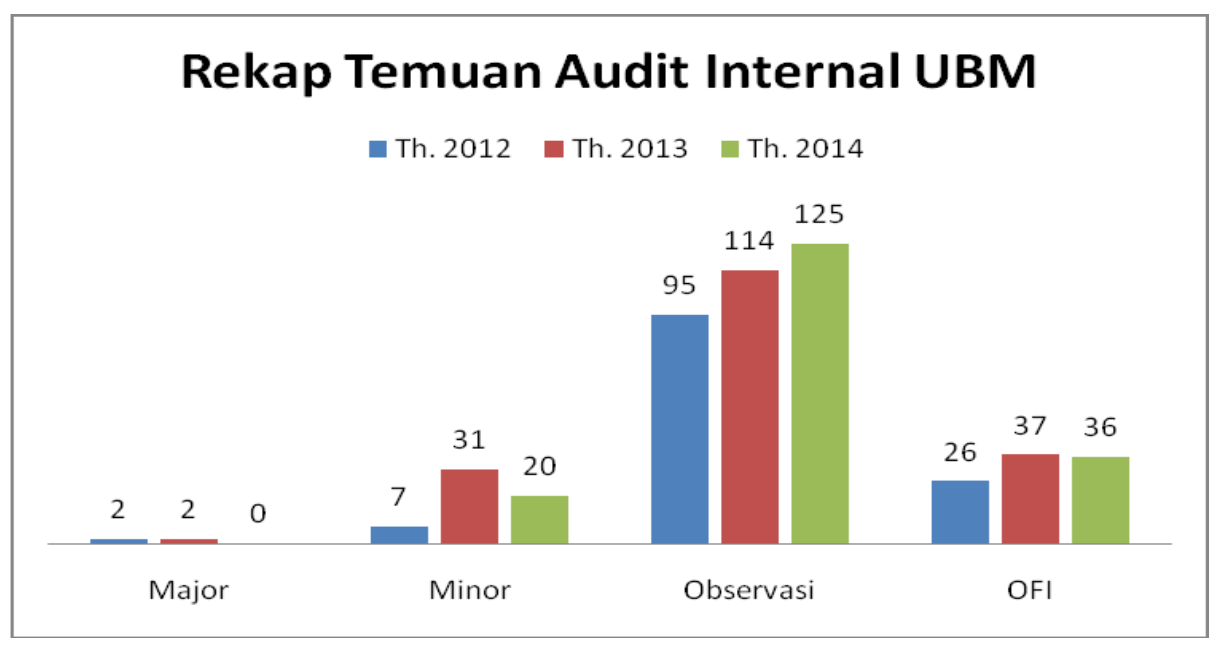

Gambar 1.1 Rekap Temuan Audit Internal UBM

Dari kondisi ini terlihat bahwa total temuan tahun 2013 lebih banyak dari tahun 2012. Meskipun tahun 2014 lebih sedikit dari tahun
2013, namun tetap lebih banyak dari tahun 2012. Kondisi temuan atau ketidaksesuaian yang terjadi menunjukkan pelaksanaannya 
manajemen mutu di Universitas Bunda Mulia masih perlu perbaikan yang berkelanjutan.

Untuk itulah penulis tertarik untuk melakukan penelitian dengan judul "Pengaruh Kompetensi dan Independensi Auditor terhadap Kualitas Audit pada Audit Mutu Internal Sistem 9001 : 2008 di Universitas Bunda Mulia”.

Berdasarkan uraian di atas, maka perumusan masalah dalam penelitian adalah sebagai berikut: 1) Apakah kompetensi auditor berpengaruh terhadap kualitas audit? 2) Apakah indepedensi auditor berpengaruh terhadap kualitas audit? 3) Apakah kompetensi dan Independensi auditor secara simultan berpengaruh terhadap kualitas audit?

Penelitian ini hanya untuk mengetahui bagaimana pengaruh Kompetensi dan Independensi Auditor terhadap Kualitas Audit pada Audit Mutu Internal Sistem ISO 9001 : 2008 di Universitas Bunda Mulia.

Faktor auditor sangatlah berperan dalam menjalankan sistem audit internal secara baik karena audit internal bertujuan memastikan kegiatan sistem manajemen mutu telah dijalankan sesuai dengan persyaratan standar yang telah ditetapkan.

Guna melihat kualitas audit internal yang baik di Universitas Bunda Mulia, maka penulis melihat perlu adanya penelitian yang melihat pengaruh kompetensi dan indepedensi auditor terhadap kualitas audit pada Audit Mutu Internal ISO 9001 : 2008 yang secara rutin dilaksanakan.

\section{RERANGKA TEORI DAN PERUMUSAN HIPOTESIS \\ Audit}

Auditing bagi perusahaan merupakan hal yang cukup penting karena memberikan pengaruh besar dalam kegiatan perusahaan yang bersangkutan. Pada awal perkembangannya auditing hanya dimaksudkan untuk mencari dan menemukan kecurangan serta kesalahan. Kemudian berkembang menjadi pemeriksaan laporan keuangan untuk memberikan pendapat atas kebenaran penyajian laporan keuangan perusahaan dan juga menjadi salah satu faktor dalam pengambilan keputusan. 
Menurut Suryatama $(62,2014)$ audit secara secara umum diklasifikasikan sebagai berikut:

a. Kelengkapan (Completeness). Untuk menyakinkan bahwa seluruh transaksi telah dicatat atau ada dalam jurnal secara aktual telah dimasukkan.

b. Ketepatan (Accurancy). Untuk memastikan transaksi dan saldo perkiraan yang ada telah dicatat berdasarkan jumlah yang benar, perhitungan yang benar, diklasifikasikan dan dicatat dengan tepat.

c. Eksistensi (Existence). Untuk memastikan bahasa semua harta dan kewajiban yang tercatat memiliki eksistensi atau keterjadian pada tanggal tertentu, jadi transaksi tercatat tersebut harus benar-benar telah terjadi dan tidak fiktif.

d. Penilaian (Valuation). Untuk memastikan bahwa prinsipprinsip akuntansi yang berlaku umum telah diterapkan dengan benar.

e. Klasifikasi (Classification). Untuk memastikan bahwa transaksi yang dicantumkan dalam jurnal diklasifikasikan dengan tepat. Jika terkait dengan saldo maka angkaangka yang dimasukkan didaftar klien telah diklasifikasikan dengan tepat.

f. Ketepatan (accuracy). Untuk memastikan bahwa semua transaksi dicatat pada tanggal yang benar, rincian dalam saldo akun sesuai dengan angka-angka yang dimasukkan didaftar klien telah diklasifikasikan dengan tepat.

g. Pisah Batas (Cut-Off). Untuk memastikan bahwa transaksitransaksi yang dekat tanggal neraca dicatat dalam periode yang tepat. Transaksi yang mungkin sekali salah saji adalah transaksi yang dicatat mendekati akhir suatu periode akuntansi.

h. Pengungkapan (Disclosure). Untuk menyakinkan bahwa saldo akun dan persyaratan pengungkapan yang berkaitan telah disajikan dengan wajar dalam laporan keuangan dan dijelaskan dengan wajar 
dalam isi dan catatan kaki laporan tersebut.

International

Standar

\section{Organization (ISO)}

Dalam pengertiannya, ISO adalah sebuah kata yang berasal dari Bahasa Yunani (Greek), yaitu isos yang berarti 'sama' atau 'equal'. Awalan kata "iso" juga banyak dijumpai misalnya pada kata "isometric", “isomer", “isonomy”, dan sebagainya. Berikutnya, banyak pihak melihat ketidakcocokan antara nama lengkap "International Organization for Standardization" dengan kependekannya, yaitu 'ISO', yang seharusnya adalah disingkat menjadi 'IOS'. Anggapan itu benar bila penetapan nama didasarkan pada kependekan atau singkatan. Akhirnya, sebutan ISO bukan lagi suatu kependekan, tetapi merupakan nama sebuah organisasi berkelas internasional.

ISO adalah organisasi non pemerintah yang didirikan pada tahun 1947. Misi ISO adalah meningkatkan pengembangan standarisasi dan aktivitas yang terkait di dunia dengan pandangan mempermudah pertukaran internasional dari barang dan jasa, dan untuk mengembangkan kerja sama dalam bidang aktivitas intelektual, sains, teknik dan ekonomi (Indranata, 2006). Paling sedikit 70 negara telah mengadopsi ISO series 9000 sebagai standar Sistem Manajemen Mutu.

\section{Audit Mutu}

Audit Mutu adalah pemeriksaan secara sistematik, objektif, terdokumentasi dan mandiri untuk menetapkan apakah kegiatan sistem manajemen mutu (SMM) dan hasil yang berkaitan telah sesuai dengan pengaturan yang direncanakan, apakah pengaturanpengaturan tersebut telah diterapkan secara efektif dan sesuai dengan komitmen, kebijakan, tujuan serta sasaran mutu yang telah direncanakan atau ditetapkan untuk mencapai tujuan (Indranata, 2006).

Bayangkara (2008) Audit Mutu adalah proses sistematis, mandiri dan terdokumentasi untuk memperoleh bukti objektif dan menilainya secara objektif untuk menentukan sejauh mana kriteria audit terpenuhi audit ini dirancang untuk menilai aktivitas praktik atau kebijakan perusahaan untuk menentukan apakah perusahaan memiliki kemampuan 
untuk memenuhi standar kualitas yang telah ditetapkan dalam operasinya.

\section{Audit Internal}

Audit Internal adalah suatu kunci dalam menentukan ya atau tidaknya Mutu Manajemen Sistem yang dengan baik dirancang, diterapkan, dan efektif dalam menemui sasaran yang dinyatakan di mutu Manajemen Sistem (Raymond, 2002).

Audit Internal ISO 9001 harus dilakukan oleh perusahaan yang mengimplementasikan ISO 9001:2008 karena pada klausul 8.2.2 dalam standar nasional Indonesia ISO 9001:2008 mensyaratkan adanya internal audit yaitu organisasi harus melakukan audit internal pada selang waktu terencana untuk menentukan apakah sistem manajemen mutu:

a. memenuhi pengaturan yang direncanakan terhadap persyaratan standar ini dan persyaratan sistem manajemen mutu yang ditetapkan oleh organisasi dan

b. diterapkan dan dipelihara secara efektif.
Tujuan internal audit dalam implementasi ISO 9001:2008 adalah guna mengevaluasi sejauh mana kepatuhan atau pemenuhan organisasi atau perusahaan terhadap persyaratan-persyaratan, termasuk terhadap standar internaional ISO 9001:2008. Disamping itu juga untuk menilai efektifitas sistem manajemen mutu pada sebuah organisasi.

Mengingat pentingnya internal audit bagi efektifitas implementasi ISO 9001:2008 maka program audit, termasuk pula kompetensi sumber daya manusia yang menjalankan internal audit harus mendapat perhatian serius. Bagaimana membuat prosedur internal audit yang memadai sehingga tujuan dari internal audit ISO 9001:2008 sebagaimana tersebut di atas bisa tercapai? Hal itulah yang harus disiapkan ketika perusahaan hendak mengimplementasikan dan berusaha mendapatkan sertifikat ISO 9001:2008. Dalam hal ini konsultan ISO 9001:2008 yang ditunjuk perusahaan memiliki peran strategis, apakah nantinya internal audit akan bisa berjalan dengan baik atau tidak. 


\section{Audit Eksternal}

Dalam hal aktivitas Audit Internal diberikan peran utama untuk bertanggung jawab dalam investigasi kecurangan, maka harus dipastikan bahwa tim yang bertugas untuk itu memiliki keahlian yang cukup mengenai skema-skema kecurangan, teknik investigasi, ketentuan perundang-undangan dan hukum yang berlaku, serta pengetahuan dan keahlian lain yang dibutuhkan dalam investigasi. Tenaga staf yang diperlukan dapat diperoleh dari dalam (in-house), outsourcing, atau kombinasi dari keduanya.

Dalam beberapa kasus, audit internal juga dapat menggunakan staf nonaudit dari unit lain di dalam organisasi untuk membantu penugasan. Hal ini sering terjadi bila keahlian yang diperlukan beragam dan tim harus dibentuk dengan segera. Dalam hal organisasi membutuhkan ahli eksternal.

Adapun proses audit eksternal yang dilakukan oleh badan audit eksternal adalah sebagai berikut:

1. Pengiriman dokumentasi sistem mutu (quality manual, quality procedure, quality plan) ke Badan Sertifikasi.
2. Kunjungan awal: biasanya proses ini dilakukan untuk mengecek atau melihat kesiapan suatu organisasi atau perusahaan.

3. Pre-audit: audit yang dilakukan sebelum audit sertifikasi yang tujuannya untuk lebih meningkatkan persiapan audit sebenarnya (assessment) dan sifatnya tidak mutlak (boleh tidak dilakukan, melainkan langsung audit).

4. Audit sistem manajemen mutu: proses audit terhadap sistem mutu meliputi pemeriksaan quality manual, quality procedure, pemeriksaan di lapangan di semua bagian/ divisi/ departemen.

5. Laporan hasil auditt: langsung dibuat setelah selesai audit dan dibacakan pada saat closing meeting audit.

6. Penyerahan sertifikat: organisasi atau perusahaan layak mendapatkan sertifikat jika hasil audit telah sesuai dengan sistem manajemen 
mutu ISO 9001:2008 yang telah dibuat tanpa temuan major.

7. Audit surveillance: audit yang dilakukan secara berkala yaitu minimal 6 (enam) bulan sekali untuk memastikan konsistensi penerapan sistem manajemen mutu ISO 9001:2008 berikut improvement-nya.

8. Audit renewal: audit yang dilakukan untuk pembaharuan (revisi) sertifikat ISO 9001:2008, setiap 3 (tiga) tahun sekali.

\section{Kualitas Audit}

Seorang auditor memiliki kebebasan yang cukup luas untuk mendapat akses informasi dengan melakukan interaksi dalam bentuk kegiatan dengan beragam teknik pendekatan. Audit pada dasarnya untuk menetukan kesesuaian sistem dengan standar yang digunakan.

Audit yang berkualitas pada sistem ISO ini adalah audit yang dapat menghasilkan nilai tambah, artinya proses audit menjadi sesuatu yang lebih berguna terutama untuk perusahaan atau organisasi.

\section{Auditor}

Orang atau sebuah organisasi yang melakukan proses audit dinamakan auditor (Suryatama, 2014). Berikut adalah beberapa peran auditor secara umum, baik auditor internal maupun auditor eksternal:

a. Bukan lagi sebagai watchdog, tetapi sebagai konsultan yang dapat memberikan nilai tambah bagi operasional organisasi.

b. Menelaah dan menilai kebaikan, memadai tidaknya dan penerapan system pengendalian manajemen, struktur pengendalian internal, dan pengendalian operasional lainnya serta mengembangkan pengendalian yang efektif dengan biaya yang tidak terlalu mahal.

c. Memastikan ketaatan terhadap kebijakan, rencana dan prosedur-prosedur yang telah ditetapkan oleh manajemen.

d. Memastikan bahwa pengelolaan data rekaman yang dikembangkan dalam organisasi dapat dipercaya. 
e. Menilai mutu pekerjaan setiap bagian dalam melaksanakan tugas yang diberikan oleh manajemen.

f. Menyarankan perbaikan operasional dalam rangka meningkatkan efesiensi dan efektifitas.

\section{Kompetensi}

Kompetensi

adalah

keseluruhan

pengetahuan,

kemampuan atau keterampilan dan sikap kerja ditambah atribut kepribadian yang dimiliki oleh seseorang yang mencakup kemampuan berfikir kreatif, keluasan pengetahuan, kecerdasan emosional, pengalaman, daya juang, sikap positif, keterampilan kerja serta kondisi kesehatan yang baik dan biasa dibuktikan atau diperagakan dalam melaksanakan tugas dan tanggung jawab yang dibebankan kepadanya.

Kompetensi auditor dalam memberikan jaminan yang wajar bahwa laporan keuangan bebas dari salah saji material, baik yang disebabkan oleh kesalahan atau penipuan, dapat diklasifikasikan ke dalam empat bidang: kompetensi profesional, kompetensi teknis, proses kompetensi dan kompetensi pelaporan (Suryatama, 2014).

1. Professional competencies. Standar umum pertama dari apa yang disebut sepuluh generally accepted auditing standards (GAAS) mensyaratkan bahwa auditor harus mengikuti pelatihan profesional dan memiliki pendidikan, pengalaman, dan sertifikasi dalm memberikan pernyataan audit keuangan.

2. Technical competencies, mengacu pada pengetahuan auditor tentang standar profesional yang relevan, aturan, hukum dan peraturan dan teknis pemahaman dan pengetahuan industri bisnis klien mereka, proses pelaporan keuangan corporate governance dan pengendalian internal secara efektif dalam melakukan audit. Kantor akuntan publik sering dikritik dalam menugaskan staf auditor yang tidak berpengalaman dalam keterlibatan audit, dengan tidak ada pengawasan yang tepat atau kompetensi teknis. 
3. Process

competencies,

berkaitan dengan kemampuan atau kompetensi auditor untuk memilih prosedur pengumpulan bukti yang sesuai (tes kontrol, substantif tes) dan untuk melaksanakan prosedur audit secara efektif. Banyak auditor menggunakan pendekatan berbasis resiko yaitu prosedur mereka berfokus pada daerah beresiko yang mengancam efektivitas pengendalian internal atau pelaporan keuangan dan keandalan dan integritas laporan keuangan.

4. Reporting competencies, merujuk kepada kemampuan dan keikhlasan auditor untuk menemukan salah saji yang material dan melaporkan temuan salah saji tersebut.

Untuk menjadi seorang auditor, maka kompetensi auditor ditentukan sebagai berikut: (Priyadi, 2011)

1. Telah dilatih oleh lembaga pelatihan atau oleh auditor yang terdaftar. Pelatihan disertai sertifikat yang dikeluarkan lembaga pelatihan.
Lama pelatihan adalah minimal 2 (dua) hari.

2. Pendidikan minimal Sekolah Menengah Umum.

3. Pengalaman kerja manajemen mutu atau manajemen lingkungan yang dimiliki adalah telah bekerja di organisasi/ perusahaan tersebut minimal 2 (dua) tahun.

Kompetensi auditor menurut Elfarini (2007) yaitu:

1. Pengetahuan. Pengetahuan diukur dari seberapa tinggi pendidikan seorang auditor karena dengan demikian auditor akan mempunyai semakin banyak pengetahuan (pandangan) mengenai bidang yang digelutinya sehingga dapat mengetahui berbagai masalah secara lebih mendalam, selain itu auditor akan lebih mudah dalam mengikuti perkembangan yang semakin kompleks.

2. Pengalaman. Auditor yang berpengalaman mempunyai pemahaman yang lebih baik, juga lebih mampu memberi penjelasan yang masuk akal. 


\section{Indepedensi}

Menurut Arens (2008),
indepedensi dapat diartikan
mengambil sudut pandang yang tidak
bias. Auditor tidak hanya harus
independen dalam fakta, tetapi juga
harus independen dalam penampilan.
Indepedensi auditor adalah tidak
mudah dipengaruhi, yang artinya
tidak dibenarkan memihak
kepentingan siapapun. Auditor
berkewajiban untuk jujur tidak hanya
memihak auditee atau manajemen,
tetapi kepada sistem Manajemen
Mutu yang seharusnya dijalankan.
Menurut Elfarini (2007)
mengukur independensi diukur
melalui lama hubungan dengan klien,
tekanan dari klien, telaah dari rekan
auditor dan pemberian jasa non audit
(klien yang dimaksud adalah
auditee)

1. Lama hubungan dengan klien. Penugasan audit yang terlalu lama kemungkinan dapat mendorong akuntan publik kehilangan independensinya karena akuntan publik tersebut merasa puas, kurang inovasi, dan kurang ketat dalam melaksanakan prosedur audit. Sebaliknya penugasan audit yang lama kemungkinan dapat pula meningkatkan independensi karena akuntan publik sudah familiar, pekerjaan dapat dilaksanakan dengan efisien dan lebih tahan terhadap tekanan klien

2. Tekanan dari klien.

Setiap auditor harus mempertahankan integritas dan objektivitas dalam menjalankan tugasnya dengan bertindak jujur, tegas, tanpa pretensi sehingga dia dapat bertindak adil, tanpa dipengaruhi tekanan atau permintaan pihak tertentu untuk memenuhi kepentingan pribadinya.

3. Telaah dari rekan auditor (peer review)

Manfaat yang diperoleh dari peer review antara lain mengurangi resiko litigation, memberikan pengalaman positif, mempertinggi moral pekerja, memberikan competitive edge dan lebih meyakinkan klien atas kualitas jasa yang diberikan.

4. Jasa non audit 
Pemberian jasa selain jasa audit berarti auditor telah terlibat dalam aktivitas manajemen klien. Jika pada saat dilakukan pengujian laporan keungan klien ditemukan kesalahan yang terkait dengan jasa yang diberikan auditor tersebut. Kemudian auditor tidak mau reputasinya buruk karena dianggap memberikan alternatif yang tidak baik bagi kliennya. Maka hal ini dapat mempengaruhi kualitas audit dari auditor tersebut.

\section{Kualitas Audit}

Seorang auditor memiliki kebebasan yang cukup luas untuk mendapat akses informasi dengan melakukan interaksi dalam bentuk kegiatan dengan beragam teknik pendekatan. Audit pada dasarnya untuk menentukan kesesuian sistem dengan standar yang digunakan.

Elfarini (2007) bahwa kualitas audit merupakan segala kemungkinan (probability) dimana auditor pada saat mengaudit dapat menemukan pelanggaran yang terjadi dalam proses audit dan melaporkannya di mana dalam melaksanakan tugasnya tersebut auditor berpedoman pada standar auditing dan kode etik yang relevan.

Audit yang berkualitas pada sistem ISO adalah audit yang dapat menghasilkan nilai tambah, artinya proses audit menjadi sesuatu yang lebih berguna, terutama untuk perusahaan atau organisasi (Zuhrawaty, 2009). Kriteria nilai tambah bagi perusahaan adalah:

a. Memberikan informasi kepada top manajemen tentang kemampuan perusahaan dalam mencapai sasaran mutu.

b. Mengidentifikasikan masalah yang apabila diselesaikan dapat meningkatkan performance perusahaan.

c. Mengidentifikasikan peluang peningkatan dan kemungkinan area yang beresiko.

Uraian dari kualitas audit di atas dapat diketahui dengan hasil ketidaksesuaian yang dapat mengidentifikasi masalah dan apabila diselesaikan dapat meningkatkan performance perusahaan atau organisasi. Para auditor dalam hal ini akan memberi nilai kategori terhadap hasil audit sesuai klasifikasi temuan sebagai 
berikut: (quality procedur UBM, 2015)

1. Sesuai. Bila penerapan sistem mutu oleh auditee sudah sesuai sebagaimana yang ditentukan dalam dokumen sistem mutu (manual prosedur, instruksi kerja, dan formulir).

2. Ketidaksesuain major.

a. Bila ditemukan adanya persyaratan standar sistem manajemen terpadu yang tidak dipenuhi atau dilaksanakan.

b. Bila ditemukan adanya sistem atau prosedur yang tidak memenuhi salah satu klausal atau persyaratan standar sistem manajemen terpadu dan sifat kesalahannya fatal.

c. Bila ditemukan sejumlah ketidaksesuaian minor yang cenderung berlawanan dengan salah satu persyaratan standar sistem manajemen terpadu dan penyimpangan tersebut terjadi di beberapa

$$
\begin{aligned}
& \text { tempat sehingga } \\
& \text { membuktikan } \quad \text { adanya } \\
& \text { kesalahan sistem } \quad \text { atau } \\
& \text { prosedur } \\
& \text { keseluruhan. }
\end{aligned}
$$

Contoh yang termasuk dalam klasifikasi major yaitu:

1) Sistem mutu tidak mencakup satu atau lebih dari persyaratan yang terdapat dalam ISO yang digunakan.

2)Ada satu dokumen kelulusan mahasiswa yang hilang dan tidak dapat ditemukan.

3)Proses yang dijalankan, tidak sesuai dengan SOP yang berlaku atau tidak melakukan review serta usulan perubahan dokumen ke unit penjaminan mutu.

3. Ketidaksesuaian minor.

a. Bila ditemukan ketidaklengkapan

dokumen dan/ atau rekaman dalam

pelaksanaan sistem manajemen terpadu.

b. Bila ditemukan ketidaksesuaian dalam pelaksanaan dokumen sistem mutu (manual prosedur, instruksi kerja, 
dan formulir) namun tidak berdampak serius terhadap sistem manajemen terpadu.

Contoh yang termasuk dalam klasifikasi minor yaitu:

1) Tidak memiliki program kerja tahunan yang terdokumentasi dan tidak melakukan.

2) Pembuatan laporan kegiatan tidak sesuai dengan ketentuan yang berlaku yaitu 7 hari kerja, akan tetapi sampai saat ini belum dibuatkan.

3) Keputusan rapat tanpa dokumentasi pendukung. pemantauan terhadap pencapaian sasaran kerja (WP \& KPI).

4. Ketidaksesuaian Observasi.

a. Jika berhubungan dengan adanya peluang untuk improvement proses.

b. Hal-hal yang berpotensi menjadi masalah serta menimbulkan

ketidaksesuaian di masamasa mendatang.

Contoh yang termasuk dalam klasifikasi observasi yaitu:
1) Tidak adanya bukti atau pencatatan atas kegiatan yang telah dilakukan.

2) Karyawan baru, yang sudah bergabung dengan institusi belum mendapatkan pelatihan induksi.

5. OFI (Opportunities for Improvement). Saran yang bisa menjadikan improvement dicatat dalam klasifikasi OFI.

Menurut De Angelo (1981) yang dikutip dari Prabowo (2010) mendefinisikan kualitas audit adalah sebagai joint probability bahwa auditor akan menemukan dan melaporkan penyimpangan dalam sistem akuntansi klien. Di mana probability yang ditemukan auditor tergantung dari kualitas pemahaman auditor (kompetensi) sedangkan pelaporan yang disajikan tergantung dari indepedensi auditor.

\section{DESAIN PENELITIAN}

Berdasarkan referensi di atas maka diperoleh kerangka pemikiran sebagai berikut: 


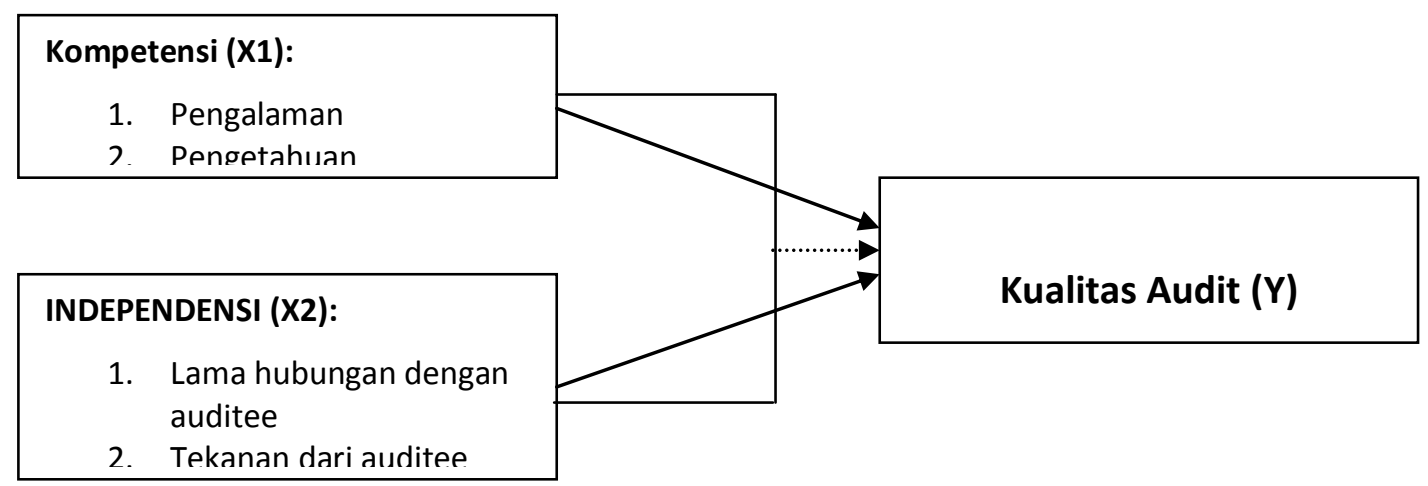

Bagan 1: . Kerangka Pemikiran

\section{METODE PENELITIAN}

Metode yang penulis lakukan dalam penelitian ini adalah metode kuantitatif yang data-data terkumpul diolah dengan metode statistik.

\section{Metodologi pengumpulan Data}

a. Studi Literatur.

Digunakan untuk mencari teori-teori/penelitian lain yang mendukung yang sudah ada dari para ahli sebelumnya terhadap pemecahan dari permasalahan yang ditemukan oleh penulis.

b. Studi Lapangan (Field Research)

Cara metode ini digunakan penelitian yang dilakukan secara langsung ke lapangan menggunakan kuesioner.

\section{Populasi dan Sampel}

Dalam penelitian ini tidak menggunakan sampel melainkan menggunakan populasi karyawan yang menjadi auditor internal yang ada di lingkungan Universitas Bunda Mulia karena jumlahnya masih memungkinkan untuk dicapai secara populasi. Menurut Sugiyono (2009) jumlah sampel yaitu 100 persen mewakili populasi adalah sama dengan jumlah anggota populasi itu sendiri. Makin besar jumlah sampel mendekati populasi, maka peluang kesalahan generalisasi semakin kecil. Analisis ini juga dapat meramalkan nilai variabel dependen, jika seluruh variabel independen sudah diketahui nilainya dan semua koefisien regresi parsialnya sudah dihitung (Supranto, 2009) di mana model regresi linear berganda untuk 
menguji pengaruh faktor penentu kualitas audit.

$$
\mathbf{Y}=\mathbf{b}_{0}+\mathbf{b}_{1} \mathbf{X}_{1}+\mathbf{b}_{2} \mathbf{X}_{2}+\varepsilon
$$

\section{Keterangan:}

$\mathrm{Y}=$ kualitas audit

$\mathrm{X}_{1}=$ kompetensi

$\mathrm{X}_{2}=$ independensi

$\mathrm{b}_{0}=$ konstanta

$b_{1} b_{2}=$ dugaan koefisien regresi

$\varepsilon=$ komponen kesalahan pengukuran

\section{HASIL DAN PEMBAHASAN}

\section{Profil Responden}

Setelah proses rekapitulasi data, maka didapat gambaran mengenai profil responden auditor internal di Universitas Bunda Mulia yang dapat dilihat pada tabel di bawah ini:

Gambar 1. Proporsi menurut jenis kelamin

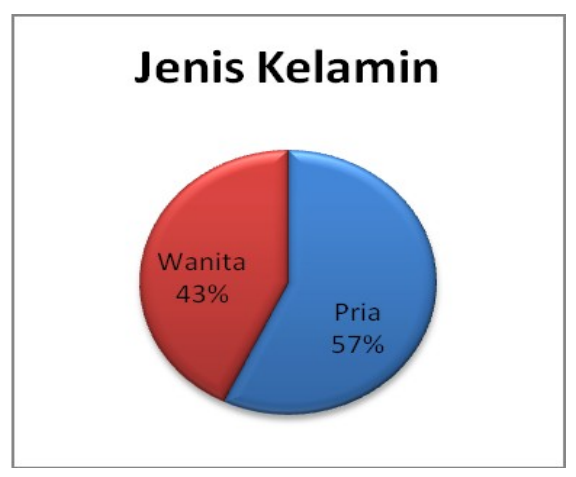

Sumber: Hasil Olahan Data Primer, 2015

Gambar 1. Profil Jenis Kelamin Auditor Internal
Berdasarkan grafik di atas terlihat bahwa profil jenis kelamin auditor internal pria sebesar $57 \%$ dan wanita $43 \%$.

Gambar 2. Jenjang Pendidikan

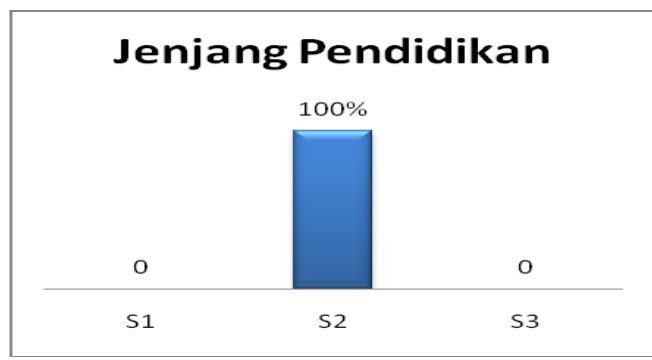

Sumber: Hasil Olahan Data Primer, 2015

Gambar 2. Profil Jenjang Pendidikan Auditor Internal

Berdasarkan grafik di atas terlihat bahwa profil jenjang pendidikan terakhir auditor internal seluruhnya adalah $\mathrm{S} 2$. 
Gambar 3. Lama bekerja

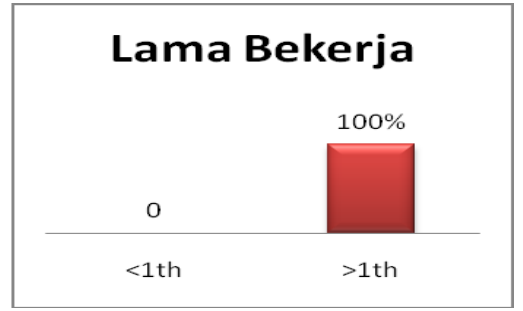

Sumber: Hasil Olahan Data Primer, 2015

Berdasarkan grafik di atas terlihat bahwa profil lama bekerja auditor internal di Universitas Bunda Mulia seluruhnya adalah $>1$ th.

Gambar 4. Profil Lama Menjadi Auditor Internal

\section{Lama menjadi Auditor Internal}

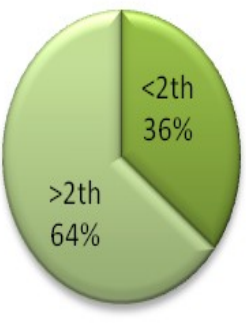

Sumber: Hasil Olahan Data Primer, 2015

Berdasarkan grafik di atas terlihat bahwa profil lama menjadi auditor internal di Universitas Bunda
Mulia yang $>2$ th sebanyak $64 \%$ dan $<2$ th sebanyak $36 \%$.

\section{Hasil Uji Validitas dan Uji Reliabilitas}

Untuk memastikan keabsahan dan keandalan kuesioner yang telah didesain, maka sebagai tahap awal dilakukan pengujian kuesioner awal (pre-test). Penyebaran kuesioner dilakukan pada tanggal 30 Juli - 06 Agustus 2015 dan terkumpul sebanyak 14 kuesioner. Hasil pengujian terhadap kuesioner ini dijabarkan dalam sub bab berikut:

\section{Hasil Uji Validitas}

Uji validitas dilakukan untuk memastikan bahwa variabel memiliki kemampuan dan kecermatan yang baik untuk mengungkap hal-hal yang ingin diketahui. Adapun hasil uji validitas dapat dilihat pada tabel dibawah ini: 
Tabel 1. Hasil Uji Validitas Variabel Kompetensi

\begin{tabular}{|c|c|c|c|}
\hline Kode & Pertanyaan & $\begin{array}{l}\text { Corrected } \\
\text { Item Total } \\
\text { Correction }\end{array}$ & Keterangan \\
\hline PT1 & $\begin{array}{l}\text { Auditor internal perlu mengerti } \\
\text { seluruh klausal sesuai ISO yang } \\
\text { digunakan }\end{array}$ & .380 & Valid \\
\hline PT2 & $\begin{array}{l}\text { Auditor internal } \quad \text { perlu } \\
\text { mengetahui } \\
\text { departemen yang akan diaudit }\end{array}$ & .541 & Valid \\
\hline PT3 & $\begin{array}{l}\text { Auditor internal perlu } \\
\text { memahami kondisi departemen } \\
\text { yang akan diaudit }\end{array}$ & .456 & Valid \\
\hline PT4 & $\begin{array}{l}\text { Dalam melakukan audit yang } \\
\text { baik, seorang auditor internal } \\
\text { membutuhkan pengetahuan yang } \\
\text { diperoleh dari tingkat } \\
\text { pendidikan formal (D3, S1) }\end{array}$ & .108 & Tidak Valid \\
\hline PT5 & $\begin{array}{l}\text { Dalam melakukan audit yang } \\
\text { baik, seorang auditor internal } \\
\text { membutuhkan pelatihan auditor } \\
\text { dari lembaga yang ditunjuk oleh } \\
\text { perusahaan }\end{array}$ & .825 & Valid \\
\hline PL1 & $\begin{array}{l}\text { Auditor internal yang memiliki } \\
\text { banyak pengalaman dalam } \\
\text { bidang audit dengan berbagai } \\
\text { macam karakter auditee, akan } \\
\text { menghasilkan audit yang lebih } \\
\text { baik }\end{array}$ & .020 & Tidak Valid \\
\hline PL2 & $\begin{array}{l}\text { Auditor internal yang pernah } \\
\text { mengaudit departemen yang } \\
\text { sudah tertata rapi, baik dari SOP } \\
\text { maupun pelaksanaannya } \\
\text { dilapangan, akan mudah } \\
\text { mengaudit di departemen yang } \\
\text { kurang baik dalam segala } \\
\text { penyusunannya }\end{array}$ & .713 & Valid \\
\hline PL3 & $\begin{array}{l}\text { Auditor internal yang sudah } \\
\text { banyak mengaudit, tetapi audit } \\
\text { yang dilakukan berikutnya } \\
\text { belum tentu lebih baik dari audit } \\
\text { sebelumnya }\end{array}$ & .456 & Valid \\
\hline
\end{tabular}

Sumber: Hasil olahan data SPSS, 2015

Berdasarkan hasil pengujian validitas

dari variabel kompetensi, terdapat 2 (dua) indikator yang tidak valid yaitu: 
a. PT4: Dalam melakukan audit yang baik, seorang auditor internal membutuhkan pengetahuan yang diperoleh dari tingkat pendidikan formal (D3, S1)

b. PL1: Auditor internal yang memiliki banyak pengalaman dalam bidang audit dengan berbagai macam karakter auditee, akan menghasilkan audit yang lebih baik

Indikator tersebut tidak digunakan sehingga menyisakan 6 (enam) indikator yang digunakan untuk menilai variabel kompetensi.

Tabel 2. Hasil Uji Validitas Variabel Independensi

\begin{tabular}{|c|c|c|c|}
\hline Kode & Pertanyaan & $\begin{array}{l}\text { Corrected } \\
\text { Item Total } \\
\text { Correction }\end{array}$ & Keterangan \\
\hline LH1 & $\begin{array}{l}\text { Auditor internal sebaiknya tidak } \\
\text { mengaudit auditee yang sama } \\
\text { pada periode audit berikutnya }\end{array}$ & .242 & Valid \\
\hline LH2 & $\begin{array}{l}\text { Auditor internal perlu bersifat } \\
\text { independen dalam melakukan } \\
\text { audit walaupun telah lama } \\
\text { menjalin hubungan dengan } \\
\text { auditee }\end{array}$ & .366 & Valid \\
\hline LH3 & $\begin{array}{l}\text { Auditor internal melaporkan } \\
\text { semua kesalahan auditee } \\
\text { walaupun auditor sudah lama } \\
\text { berhubungan kerja dengan } \\
\text { auditee }\end{array}$ & .127 & Tidak Valid \\
\hline LH4 & $\begin{array}{l}\text { Auditor dalam mengungkapkan } \\
\text { hasil temuan tidak terpengaruh } \\
\text { oleh kedekatan hubungan } \\
\text { dengan auditee }\end{array}$ & .422 & Valid \\
\hline LH5 & $\begin{array}{l}\text { Proses audit harus dijalankan } \\
\text { serius walaupun antara auditor } \\
\text { dengan auditee memiliki } \\
\text { hubungan kerja yang dekat }\end{array}$ & .592 & Valid \\
\hline TA1 & $\begin{array}{l}\text { Umumnya auditor internal } \\
\text { kurang berani melaporkan } \\
\text { kesalahan auditee karena auditee } \\
\text { lebih senior dari auditor }\end{array}$ & .244 & Valid \\
\hline TA2 & $\begin{array}{l}\text { Tingginya posisi auditee dari } \\
\text { auditor dalam suatu struktural } \\
\text { perusahaan akan mempengaruhi }\end{array}$ & .337 & Valid \\
\hline
\end{tabular}




\begin{tabular}{|l|l|l|l|}
\hline & auditor dalam mengaudit & & \\
\hline TA3 & $\begin{array}{l}\text { Sifat temperamental dari auditee } \\
\text { akan mempengaruhi auditor } \\
\text { dalam proses audit }\end{array}$ & .172 & Tidak Valid \\
\hline
\end{tabular}

Sumber: Hasil olahan data SPSS, 2015

Berdasarkan hasil pengujian validitas dari variabel kompetensi, terdapat 2 (dua) indikator yang tidak valid yaitu:

a. LH3: Auditor internal melaporkan semua kesalahan auditee walaupun auditor sudah lama berhubungan kerja dengan auditee

Tabel 3. Hasil Uji Validitas Variabel Kualitas Audit

\begin{tabular}{|c|l|c|c|}
\hline Kode & \multicolumn{1}{|c|}{ Pertanyaan } & $\begin{array}{l}\text { Corrected } \\
\text { Item Total } \\
\text { Correction }\end{array}$ & Keterangan \\
\hline KL1 & $\begin{array}{l}\text { Auditor internal sebaiknya tidak } \\
\text { mengaudit auditee yang sama } \\
\text { pada periode audit berikutnya }\end{array}$ & -.032 & Tidak Valid \\
\hline KL2 & $\begin{array}{l}\text { Auditor internal perlu bersifat } \\
\text { independen dalam melakukan } \\
\text { audit walaupun telah lama } \\
\text { menjalin hubungan dengan } \\
\text { auditee }\end{array}$ & $\begin{array}{l}\text { Auditor internal melaporkan } \\
\text { semua kesalahan auditee } \\
\text { Kalaupun auditor sudah lama } \\
\text { berhubungan kerja dengan } \\
\text { auditee .58 }\end{array}$ & Valid \\
\hline KL4 & $\begin{array}{l}\text { Auditor dalam mengungkapkan } \\
\text { hasil temuan tidak terpengaruh } \\
\text { oleh kedekatan hubungan } \\
\text { dengan auditee }\end{array}$ & .748 & Valid \\
\hline KL5 & $\begin{array}{l}\text { Proses audit harus dijalankan } \\
\text { serius walaupun antara auditor } \\
\text { dengan auditee memiliki } \\
\text { hubungan kerja yang dekat }\end{array}$ & -.089 & Tidak Valid \\
\hline
\end{tabular}

Sumber: Hasil olahan data SPSS, 2015 b. TA3: Sifat temperamental dari auditee akan mempengaruhi auditor dalam proses audit Indikator tersebut tidak digunakan sehingga menyisakan 6 (enam) indikator yang digunakan untuk menilai variabel independensi. 
Berdasarkan hasil pengujian validitas dari variabel kompetensi, terdapat 2 (dua) indikator yang tidak valid yaitu:

a. KL1: Auditor internal sebaiknya tidak mengaudit auditee yang sama pada periode audit berikutnya

b. KL5: Proses audit harus dijalankan serius walaupun antara auditor dengan auditee memiliki hubungan kerja yang dekat

Indikator tersebut tidak digunakan sehingga menyisakan 3 (tiga) indikator yang digunakan untuk menilai variabel kualitas audit.

\section{Hasil Uji Reliabilitas}

Uji reliabilitas dilakukan untuk memastikan bahwa berapa kalipun instrumen atau kuesioner yang terkumpul diulang, hasilnya akan tetap sama. Adapun hasil uji reliabilitas dapat dilihat pada tabel dibawah ini:

Tabel 4. Hasil Uji Reliabilitas

\begin{tabular}{|c|r|}
\hline \multicolumn{2}{|c|}{ Reliability Statistics } \\
\hline $\begin{array}{c}\text { Cronbach's } \\
\text { Alpha }\end{array}$ & N of Items \\
\hline .708 & 22 \\
\hline
\end{tabular}

Sumber: Hasil olahan data SPSS, 2015

Menurut Ghozali (2005;88) yang dikutip dari Lestari (2013), nilai reliabilitas yang kurang dari 0,6 adalah kurang baik (tidak reliabel), sedangkan diatas 0,6 sampai 0,7 dapat diterima dan reliabilitas diatas 0,7 adalah baik. Berdasarkan nilai koefisien Alpha Cronbach pada tabel 4.4. terlihat nilainya $>0,6$ maka dapat disimpulkan bahwa semua indikator dari variabel independen maupun dependen. adalah reliabel 


\section{Uji Asumsi Klasik}

\section{Uji Normalitas}

Gambar 5. Hasil Uji Normalitas

Normal P-P Plot of Regression Standardized Residual

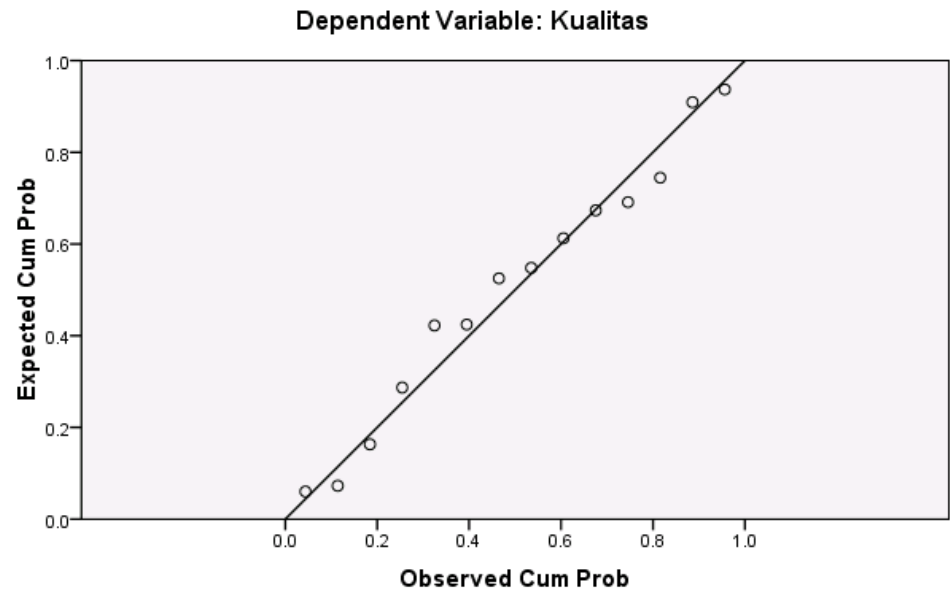

Sumber: Hasil olahan data SPSS, 2015

Berdasarkan gambar 5 terlihat diagonal maka dapat dikatakan penyebarannya di sekitar garis bahwa data terdistribusi normal.

\section{Uji Multikoliniearitas}

Tabel 5 Hasil Uji Multikoliniearitas

\begin{tabular}{|c|c|c|c|c|c|c|c|c|}
\hline \multicolumn{9}{|c|}{ Coefficients $^{a}$} \\
\hline \multirow[b]{2}{*}{ Madel } & & \multicolumn{2}{|c|}{ Unstandardized Coefficients } & \multirow{2}{*}{$\begin{array}{c}\text { Standardized } \\
\text { Coefficients } \\
\text { Beta } \\
\end{array}$} & \multirow[b]{2}{*}{$t$} & \multirow[b]{2}{*}{ Siq. } & \multicolumn{2}{|c|}{ Collinearity Statistics } \\
\hline & & $\mathrm{B}$ & Std. Error & & & & Tolerance & $\mathrm{VIF}$ \\
\hline \multirow[t]{3}{*}{1} & (Constant) & 7.558 & 3.301 & & 2.289 & .043 & & \\
\hline & Kompetensi & .292 & .109 & .731 & 2.674 & .022 & .652 & 1.534 \\
\hline & Independensi & -.059 & 178 & -.090 & -.331 & .747 & .652 & 1.534 \\
\hline
\end{tabular}

a. Dependent Variable: Kualitas

Sumber: Hasil olahan data SPSS, 2015

Hasil olahan data pada tabel $5 . \quad 1,534<$ dari 10 dan nilai Tolerance memperlihatkan bahwa nilai dari kedua variabel tersebut $>$ dari Variance Inflation Factor (VIF) dari $\quad 0,1$ maka maka model regresi yang kompetensi dan independensi sebesar 
terbentuk tidak terjadi multikoliniearitas.

\section{Uji Heteroskedastisitas}

Gambar 6. Hasil Uji Heteroskedastisitas

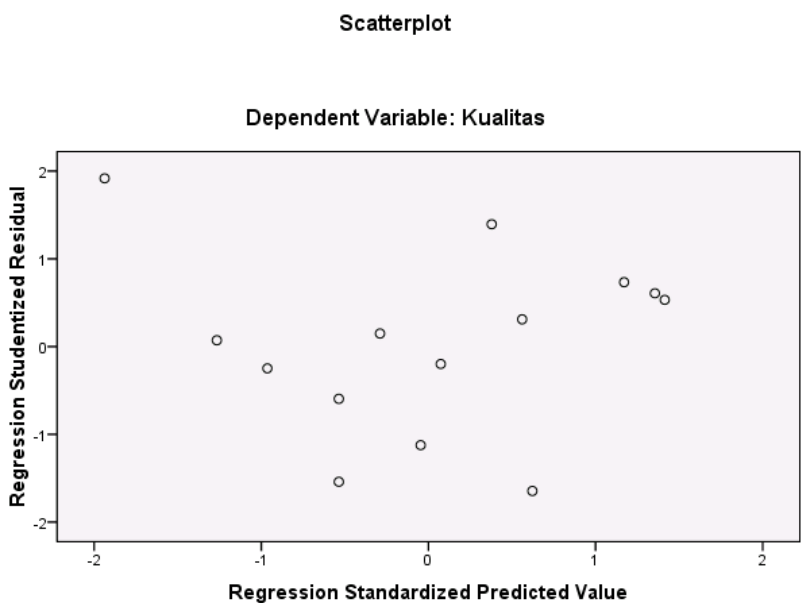

Sumber: Hasil olahan data SPSS, 2015

Berdasarkan gambar 6. terlihat disimpulkan tidak terjadi penyebaran data pada scatter plot heteroskedastisitas tetapi tidak teratur dan tidak membentuk homokedastisitas. pola tertentu, maka dapat

\section{Uji Otokorelasi}

Tabel 6. Hasil Uji Otokorelasi

Model Summary

\begin{tabular}{|l|l|l|r|r|r|}
\hline $\begin{array}{l}\text { Mode } \\
n\end{array}$ & $\mathrm{R}$ & R Square & $\begin{array}{c}\text { Adjusted R } \\
\text { Square }\end{array}$ & $\begin{array}{c}\text { Std. Error of } \\
\text { the Estimate }\end{array}$ & $\begin{array}{c}\text { Durbin- } \\
\text { Watson }\end{array}$ \\
\hline 1 & $.681^{\mathrm{a}}$ & .464 & .367 & 1.11906 & 1.442 \\
\hline
\end{tabular}

a. Predictors: (Constant), Independensi, Kompetensi

b. Dependent Variable: Kualitas

Sumber: Hasil olahan data SPSS, 2015

Hasil olahan data pada tabel 6. Watson (DW) berada di antara 1 dan memperlihatkan bahwa Durbin 3, maka tidak terjadi otokorelasi. 


\section{Teknik Analisis Regresi Berganda}

Tabel 7. Model Summary

\begin{tabular}{|l|l|r|r|r|}
\hline $\begin{array}{l}\text { Mode } \\
1\end{array}$ & $\mathrm{R}$ & R Square & $\begin{array}{c}\text { Adjusted R } \\
\text { Square }\end{array}$ & $\begin{array}{c}\text { Std. Error of } \\
\text { the Estimate }\end{array}$ \\
\hline 1 & $.681^{\mathrm{a}}$ & .464 & .367 & 1.11906 \\
\hline
\end{tabular}

a. Predictors: (Constant), Independensi, Kompetensi

Sumber: Hasil olahan data SPSS, 2015

Tabel 8. Coefficients Variabel

\begin{tabular}{|c|c|c|c|c|c|c|}
\hline \multirow{2}{*}{\multicolumn{2}{|c|}{ Madel }} & \multicolumn{2}{|c|}{ Unstandardized Coefficients } & $\begin{array}{c}\text { Standardized } \\
\text { Coefficients }\end{array}$ & \multirow[b]{2}{*}{$t$} & \multirow[b]{2}{*}{ Siq. } \\
\hline & & $\mathrm{B}$ & Std. Error & Beta & & \\
\hline \multirow[t]{3}{*}{1} & (Constant) & 7.558 & 3.301 & & 2.289 & .043 \\
\hline & Kompetensi & .292 & .109 & .731 & 2.674 & .022 \\
\hline & Independensi & -.059 & .178 & -.090 & -.331 & .747 \\
\hline
\end{tabular}

a. Dependent Variable: Kualitas

Sumber: Hasil olahan data SPSS, 2015

Pada tabel 7 dan 8 dapat dijabarkan dalam bentuk persamaan regresi sebagai berikut:

$\mathrm{Y}=\mathrm{b}_{0}+\mathrm{b}_{1} \mathrm{X}_{1}+\mathrm{b}_{2} \mathrm{X}_{2}+\varepsilon$

$\mathrm{Y}=7,558+0,292 \mathrm{X}_{1}+(-0.059) \mathrm{X}_{2}+$ 0,464

Besarnya nilai koefisien regresi kompetensi $\left(b_{1}\right)$ sebesar 0,292 dan mempunyai nilai signifikan $<0,05$ yang membuktikan bahwa kompetensi berpengaruh positif yang signifikan terhadap kualitas audit. Sedangkan nilai koefisien regresi independensi $\left(b_{2}\right)$ sebesar $-0,059$ dan mempunyai nilai signifikan $<0,05$ yang membuktikan bahwa independensi tidak berpengaruh positif yang signifikan terhadap kualitas audit.

Besarnya koefisien determinasi sebesar $46,4 \%$ yang membuktikan bahwa 46,4\% variabel kualitas audit dapat dijelaskan oleh variabel kompetensi dan independensi dalam model regresi sedangkan sisanya $53,6 \%$ dijelaskan oleh variabelvariabel lain di luar model penelitian ini. 
Tabel 9. Anova (Uji F)

\begin{tabular}{|c|c|c|c|c|c|c|}
\hline \multicolumn{7}{|c|}{ ANOVA ${ }^{b}$} \\
\hline & & $\begin{array}{c}\text { Sum of } \\
\text { Squares }\end{array}$ & $\mathrm{df}$ & Mean Square & $F$ & Sig. \\
\hline \multirow{3}{*}{1} & Regression & 11.939 & 2 & 5.970 & 4.767 & $.032^{a}$ \\
\hline & Residual & 13.775 & 11 & 1.252 & & \\
\hline & Total & 25.714 & 13 & & & \\
\hline
\end{tabular}

Sumber: Hasil olahan data SPSS, 2015

\section{Uji Hipotesis}

\section{Pengaruh kompetensi dan \\ independensi secara simultan \\ terhadap kualitas audit}

Uji ini untuk melihat signifikasi pengaruh kompetensi dan independensi terhadap kualitas audit. Nilai $\mathrm{F}$ hitung sebesar 4,767 > F tabel sebesar 4.11 dan nilai signifikan 0,032 < nilai alpha 0,05. Dengan demikian $\mathrm{H}_{0}$ ditolak dan $\mathrm{Ha}$ diterima.

Tabel 10. Coeficients (Uji t)

\begin{tabular}{|c|c|c|c|c|c|c|}
\hline \multicolumn{7}{|c|}{ Coefficients ${ }^{a}$} \\
\hline \multirow{2}{*}{\multicolumn{2}{|c|}{ Model }} & \multicolumn{2}{|c|}{ Unstandardized Coefficients } & \multirow{2}{*}{$\begin{array}{c}\begin{array}{c}\text { Standardized } \\
\text { Coefficients }\end{array} \\
\text { Beta }\end{array}$} & \multirow[b]{2}{*}{$t$} & \multirow[b]{2}{*}{ Sig. } \\
\hline & & B & Std. Error & & & \\
\hline \multirow[t]{3}{*}{1} & (Constant) & 7.558 & 3.301 & & 2.289 & .043 \\
\hline & Kompetensi & .292 & .109 & .731 & 2.674 & .022 \\
\hline & Independensi & -.059 & .178 & -.090 & -.331 & .747 \\
\hline
\end{tabular}

a. Dependent Variable: Kualitas

Sumber: Hasil olahan data SPSS, 2015

\section{Pengaruh kompetensi dan independensi terhadap kualitas audit}

Uji ini untuk mengetahui seberapa jauh variabel independen mempengaruhi terhadap variabel dependen, maka dilakukan uji t-test. Berdasarkan hasil pengolahan pada tabel 10. didapatkan bahwa:

Variabel kompetensi terhadap variabel kualitas audit $\mathrm{t}$ hitung sebesar 2,674 dan signifikansi sebesar 0,022 yang berarti bahwa $\mathrm{H}_{\mathrm{a}}$ diterima yaitu terdapat pengaruh positif dan signifikan antara kompetensi terhadap kualitas audit.

Ini berarti korelasi positif atau semakin besar kompetensi auditor maka kualitas audit semakin meningkat.

Variabel independensi terhadap variabel kualitas audit $\mathrm{t}$ hitung 
sebesar -0.331 dan signifikansi sebesar 0,747 yang berarti bahwa $\mathrm{H}_{\mathrm{a}}$ diterima yaitu terdapat pengaruh negatif dan tidak signifikan antara independensi terhadap kualitas audit.

Ini berarti korelasi negatif atau semakin besar independensi auditor maka kualitas audit akan semakin menurun.

\section{PENUTUP}

Pada penelitian ini dihasilkan kesimpulan sebagai berikut:

Besarnya nilai koefisien regresi kompetensi $\left(\mathrm{X}_{1}\right)$ sebesar 0,022 dan mempunyai nilai signifikan $<0,05$ membuktikan bahwa kompetensi berpengaruh signifikan terhadap kualitas audit.

Besarnya nilai koefisien regresi independensi $\left(\mathrm{X}_{2}\right)$ sebesar 0,747dan mempunyai nilai signifikan $>0,05$ membuktikan bahwa independensi tidak berpengaruh signifikan terhadap kualitas audit.

Nilai F hitung sebesar 4,767 > F tabel sebesar 4.11 dan nilai signifikan 0,032 < nilai alpha 0,05. Ini berarti ada pengaruh secara simultan antara kompetensi dan independensi terhadap kualitas audit.

Saran yang dapat peneliti berikan adalah sebagai berikut:
Perlunya peningkatan kompetensi terus-menerus dari seorang auditor agar memudahkan dalam proses audit. Peningkatan keterampilan antara lain melalui pelatihan, workshop dan benchmarking. Dengan demikian diharapkan akan meningkatkan hasil kualitas audit sehingga temuan audit sangat berpengaruh pada putusan manajemen. Tanpa hal itu diperbaiki, sangat kecil kemungkinannya hasil audit sistem mutu ISO 9001 berpengaruh terhadap perusahaan.

Perlunya independensi auditor tetap dijaga meskipun tidak berpengaruh siginifikan terhadap kualitas audit.

Dari pengamatan selama penelitian, ada baiknya dilakukan penelitian lebih mendalam tentang besarnya pengaruh pendidikan dan keahlian kerja seorang auditor terhadap keputusan penilaian hasil audit internal ISO 9001. Dengan demikian hasil yang nantinya dapat memberikan informasi tentang arah pendidikan baik bagi seorang auditor sistem ISO 9001. 


\section{DAFTAR PUSTAKA}

Arens et al. 2008. Auditing and Assurances Services - An Integrated Approach. Edisi Kedua Belas. Prentice Hall.

Bayangkara, IBK. 2008, Audit Manajemen Prosedur dan Implementasi, Salemba empat, Jakarta.

Boiral, Olivier and Kouakou, Dogui. (2013). ISO auditing and the construction of trust in auditor independence. Accounting, Auditing \& Accountability Journal, Vol.26, No.8, pp.1279-1305, Emerald Group Publishing Limited.

Elfarini, Eunike Christina. 2007. Pengaruh Kompetensi dan Independensi Auditor terhadap Kualitas Audit. Skripsi. Universitas Semarang.

Gasperz V, 2008, Total Quality Management, Gramedia Pustaka Utama, Jakarta.

Indranata I., 2006, Terampil dan Sukses Melakukan Audit Mutu Internal ISO 9001: 2000, Alfabeta, Bandung.

Lestari, Verliana. 2013. Pengaruh Store Atmosphere dan Service Quality Terhadap Keputusan Konsumen Memilih Minimarket berkonsep Convenience Store dengan Menggunakan Brand Image Sebagai Intervening Variable. Tesis. Universitas Bunda Mulia.

Mohammed, Diana Mostafa and Habib, Magda Hussein. (2013). Auditor independence,

audit quality and the mandatory auditor rotation in Egypt. Education, Business and Society: Contemporary Middle Eastern Issues, Vol. 6 Iss 2 pp. 116 144. Emerald Group Publishing Limited

Raymond, J. Murphy, 2002, Implementing an ISO 9001:2000 Based Quality Management System, Government Institutes Inc., USA.

Sugiyono, 2012. Metode Penelitian Kombinasi (Mixed Methods). CV. Alfabeta. Bandung.

Sugiyono, 2009, Statistik untuk Penelitian, Alfabeta, Bandung. 